\title{
NOTES
}

\section{Methanolobus taylorii sp. nov., a New Methylotrophic, Estuarine Methanogen}

\author{
RONALD S. OREMLAND ${ }^{1}$ AND DAVID R. BOONE ${ }^{2 *}$ \\ Water Resources Division, U.S. Geological Survey, Menlo Park, California 94025, ${ }^{1}$ and Department of Environmental \\ Science and Engineering, Oregon Graduate Institute of Science \& Technology, Portland, Oregon 97291-1000 2
}

\begin{abstract}
Previously published phylogenetic studies of $16 \mathrm{~S}$ rRNA showed that methylotrophic, slightly halophilic, methanogenic strain GS-16 ${ }^{\mathrm{T}}$ ( $\mathrm{T}=$ type strain) represents a new species of bacterium. We propose the name Methanolobus taylorii for this species; strain GS-16 is the type strain.
\end{abstract}

Strain GS-16 ${ }^{\mathrm{T}}$ ( $\mathrm{T}=$ type strain) is a methylotrophic methanogen that was isolated from estuarine sediments from San Francisco Bay (4) and has been deposited in the Oregon Collection of Methanogens (Oregon Graduate Institute, Portland) as strain OCM $58^{\mathrm{T}}$. This strain was isolated by using dimethyl sulfide as the catabolic substrate (4), but it can also grow on methylamines $(13)$ and methanethiol $(8,9)$ and grew when it was inoculated into MSHA medium (6) supplemented with $20 \mathrm{mM}$ methanol as the sole catabolic substrate. Strain GS-16 ${ }^{\mathbf{T}}$ cells form methane from methylmercury (12) and dimethylselenide (16), although they cannot grow on these substrates, and form traces of ethane from diethyl sulfide (15). Methanogenesis from trimethylamine is inhibited by methyl fluoride (11) and methyl bromide (14), but not by dimethyl ether (11).

Strain GS- $16^{\mathrm{T}}$ cells did not grow in a mineral medium (MMSHA medium, which was MSHA medium with Trypticase peptones, yeast extract, and coenzyme $M$ deleted and the concentration of $\mathrm{Na}_{2} \mathrm{~S} \cdot 9 \mathrm{H}_{2} \mathrm{O}$ increased to $0.5 \mathrm{~g}$ /liter) when 20 $\mathrm{mM}$ trimethylamine was added as the sole catabolic substrate, but grew well in this medium when biotin was added.

The cells are mesophilic. In the original characterization of strain GS-16 ${ }^{\mathrm{T}}$, Oremland et al. (13) reported that this organism grew poorly at temperatures greater than $28^{\circ} \mathrm{C}$ in mineral medium containing a catabolic substrate (dimethylsulfide) and vitamins as the only organic compounds and grew fastest at $37^{\circ} \mathrm{C}$ in medium containing Trypticase peptones and yeast extract. However, during our studies of the minimum organic requirements for growth, strain GS-16 ${ }^{\mathrm{T}}$ cells grew well at $37^{\circ} \mathrm{C}$ in defined MMSHA medium containing biotin and a catabolic substrate $(20 \mathrm{mM}$ trimethylamine). It is possible that since its original isolation strain GS-16 ${ }^{\mathrm{T}}$ has acquired the ability to grow at $37^{\circ} \mathrm{C}$. Similarly, the initial description of Methanolobus tindarius Tindari $3^{\mathrm{T}}$ indicated that the optimum growth temperature for this organism was $25^{\circ} \mathrm{C}(5)$, but cultures of this strain now grow fastest at $37^{\circ} \mathrm{C}(18)$.

Strain GS-16 ${ }^{\mathbf{T}}$ is slightly halophilic, growing well in the presence of sodium concentrations between 0.2 and $1.0 \mathrm{M}$ and in the presence of $\mathrm{Mg}^{2+}$ concentrations of $15 \mathrm{mM}$ or greater (4). It grows fastest at $\mathrm{pH}$ values between 7.0 and 8.8 (4). W. B. Whitman (University of Georgia, Athens) found that the

${ }^{*}$ Corresponding author. Mailing address: Oregon Graduate Institute, P.O. Box 20000, Portland, OR 97291-1000. Fax: (503) 690-1273. Electronic mail address: boone@ese.ogi.edu. guanine-plus-cytosine content of the DNA is $40.8 \pm 0.3 \mathrm{~mol} \%$ by performing a liquid chromatographic analysis of the bases (7).

The $16 \mathrm{~S}$ rRNA sequence of strain GS-16 ${ }^{\mathrm{T}}$ was compared with the $16 \mathrm{~S}$ rRNA sequences of many other methanogens (3), and the results indicated that strain GS-16 $16^{\mathbf{T}}$ is most closely related to Methanohalophilus oregonensis WAL1 ${ }^{\mathrm{T}}$. However, the evolutionary distances are great enough that the two strains belong in separate species; these distances are as great as distances between other distinct species (3). The 16S rRNA sequences of both of these strains were similar to the sequence of Methanolobus tindarius Tindari $3^{\mathrm{T}}$, suggesting that all three species should be assigned to the genus Methanolobus, as separate species (3). The results of a comparison of the whole-cell proteins of strain GS-16 ${ }^{\mathrm{T}}$, Methanococcoides methylutens TMA-10 ${ }^{\mathrm{T}}$, Methanolobus vulcani PL-12/M ${ }^{\mathrm{T}}$, and Methanolobus siciliae $\mathrm{T} 4 / \mathrm{M}^{\mathrm{T}}$ and $\mathrm{HI} 350$ (5) support the proposed that strain GS-16 ${ }^{\mathrm{T}}$ should be placed in a new species of the genus Methanolobus. The results of a DNA hybridization study (1) confirmed that strain GS-16 ${ }^{\mathrm{T}}$ does not belong in the genus Methanohalophilus or in the genus Methanohalobium.

Strain GS-16 $6^{\mathbf{T}}$ is also physiologically distinct from species of the genus Methanolobus. In 1989, in Bergey's Manual of Systematic Bacteriology, Stetter recognized three Methanolobus species: Methanolobus tindarius, Methanolobus siciliae, and Methanolobus vulcani (18). Since then, Methanolobus siciliae has been transferred to the genus Methanosarcina as Methanosarcina siciliae (10). The two remaining species group phylogenetically with Methanohalophilus oregonensis (6), which should be transferred to the genus Methanolobus (3). Although the proposal for transfer of Methanohalophilus oregonensis has not been formalized, we believe that Methanolobus tindarius, Methanolobus vulcani, and Methanohalophilus oregonensis are three currently recognized species whose phylogenies indicate that they should be classified as Methanolobus species. Strain GS $-16^{\mathrm{T}}$ differs physiologically from these three species (Table 1), although Methanolobus vulcani has not been well characterized (18) relative to minimal standards (2). Strain GS- $16^{\mathrm{T}}$ is most similar to Methanohalophilus oregonensis WAL1 ${ }^{\mathrm{T}}$, but it has a lower $\mathrm{pH}$ range ( $\mathrm{pH} 6.8$ to 9.0 [4]) than Methanohalophilus oregonensis WAL1 ${ }^{\mathrm{T}}$ (pH 7.7 to 9.5 [6]) and it is less halophilic (strain GS-16 ${ }^{\mathrm{T}}$ does not grow in the presence of $\mathrm{NaCl}$ concentrations greater than $1.2 \mathrm{M} \mathrm{NaCl}$ [4], whereas Methanohalophilus oregonensis $\mathrm{WAL}^{\mathrm{T}}$ grows in the presence of $1.6 \mathrm{M} \mathrm{NaCl}[6]$ ). Because of the phylogenetic and physiological differences of strain GS-16 ${ }^{\mathrm{T}}$, we propose that this 
organism should be placed in a new species, Methanolobus taylorii. Strain GS-16 is the type strain of Methanolobus taylorii.

Methanolobus taylorii sp. nov. Methanolobus taylorii (tay'lor. i.i. N. L. gen. masc. n. taylorii, of Taylor; named for Barrie F. Taylor for his contributions to our understanding of the marine organosulfur cycle and for his mentorship of many students and postdoctoral associates in the field of marine microbiology).

Cells are coccoid bodies 0.5 to $1 \mu \mathrm{m}$ in diameter and sometimes grow in large clumps. Lysed by detergents. Gram negative. Nonmotile.

Cells grow by forming methane from methylamines, methylsulfides, and methanol. They form methane from dimethylselenide and methylmercury and ethane from diethylsulfide, but they cannot grow on any of these substrates, nor can they grow on methionine, dimethyl disulfide, formate, $\mathrm{H}_{2}-\mathrm{CO}_{2}$, or acetate.

Cells grow well at $37^{\circ} \mathrm{C}$, at $\mathrm{pH} 7.2$ to 8.8 , and in the presence of 0.2 to $1.2 \mathrm{M} \mathrm{NaCl}$. Very strictly anaerobic. Biotin and catabolic substrate are the only organic compounds required for growth. The guanine-plus-cytosine content of the DNA of the type strain is $40.8 \pm 0.3 \mathrm{~mol} \%$ (as determined by a chromatographic analysis of bases).

The habitat is estuarine sediments.

The type strain is GS-16 (= OCM 58 = DSM 9005).

This work was supported by grant 14-08-001-G2098 from the U.S. Geological Survey.

\section{REFERENCES}

1. Boone, D. R., I. M. Mathrani, Y. Liu, J. A. G. F. Menaia, R. A. Mah, and J. E. Boone. 1993. Isolation and characterization of Methanohalophilus portucalensis sp. nov. and DNA reassociation study of the genus Methanohalophilus. Int. J. Syst. Bacteriol. 43:430-437.

2. Boone, D. R., and W. B. Whitman. 1988. Proposal of minimal standards for describing new taxa of methanogenic bacteria. Int. J. Syst. Bacteriol. 38:212-219.

3. Boone, D. R., W. B. Whitman, and P. Rouvière. 1993. Diversity and taxonomy of methanogens, p. 35-80. In J. G. Ferry (ed.), Methanogenesis. Chapman \& Hall, New York.

4. Kiene, R. P., R. S. Oremland, A. Catena, L. G. Miller, and D. G. Capone. 1986. Metabolism of reduced methylated sulfur compounds in anaerobic sediments and by a pure culture of an estuarine methanogen. Appl. Environ. Microbiol. 52:1037-1045.

5. König, K., and K. O. Stetter. 1982. Isolation and characterization of Methanolobus tindarius sp. nov., a coccoid methanogen growing only on methanol and methylamines. Zentralbl. Bakteriol. Parasitenkd. Infektionskr. Hyg. Abt. 1 Orig. Reihe C 3:478-490.

6. Liu, Y., D. R. Boone, and C. Choy. 1990. Methanohalophilus oregonense sp. nov., a methylotrophic methanogen from an alkaline, saline aquifer. Int. J. Syst. Bacteriol. 40:111-116.

7. Mesbah, M., U. Premachandran, and W. B. Whitman. 1989. Precise measurement of the guanine-plus-cytosine content of deoxyribonucleic acid by high-performance liquid chromatography. Int. J. Syst. Bacteriol. 39:159-167.

8. Ni, S., and D. R. Boone. 1991. Isolation and characterization of a dimethylsulfide-degrading methanogen, Methanolobus siciliae $\mathrm{HI} 350$, from an oil well, characterization of $M$. siciliae $\mathrm{T} 4 / \mathrm{M}^{\mathrm{T}}$, and emendation of $M$. siciliae. Int. J. Syst. Bacteriol. 41:410-416.

9. Ni, S., and D. R. Boone. 1993. Catabolism of dimethylsulfide and methane thiol by methylotrophic methanogens, p. 796-810. In R. S. Oremland (ed.), Biogeochemistry of global change. Chapman \& Hall, New York.

10. Ni, S., C. R. Woese, H. C. Aldrich, and D. R. Boone. 1994. Transfer of Methanolobus siciliae to the genus Methanosarcina, naming it Methanosarcina siciliae, and emendation of the genus Methanosarcina. Int. J. Syst. Bacteriol. 44:357-359.

11. Oremland, R. S., and C. W. Culbertson. 1992. Evaluation of methyl fluoride and dimethyl ether as inhibitors of aerobic meth- 
ane oxidation. Appl. Environ. Microbiol. 58:2983-2992.

12. Oremland, R. S., C. W. Culbertson, and M. R. Winfrey. 1991. Methylmercury decomposition in sediments and bacterial cultures: involvement of methanogens and sulfate reducers in oxidative demethylation. Appl. Environ. Microbiol. 57:130-137.

13. Oremland, R. S., R. P. Kiene, I. M. Mathrani, M. J. Whiticar, and D. R. Boone. 1989. Description of an estuarine methylotrophic methanogen which grows on dimethyl sulfide. Appl. Environ. Microbiol. 55:994-1002.

14. Oremland, R. S., L. G. Miller, and F. E. Strohmaier. 1994. Degradation of methylbromide in anaerobic sediments. Environ. Sci. Technol. 28:514-520.

15. Oremland, R. S., M. J. Whiticar, F. E. Strohmaier, and R. P.
Kiene. 1988. Bacterial ethane formation from reduced, ethylated sulfur compounds in anoxic sediments. Geochim. Cosmochim. Acta 52:1895-1904.

16. Oremland, R. S., and J. P. Zehr. 1986. Formation of methane and carbon dioxide from dimethylselenide in anoxic sediments and by a methanogenic bacterium. Appl. Environ. Microbiol. 52:1031-1036.

17. Sowers, K. R., and J. G. Ferry. 1983. Isolation and characterization of a methylotrophic marine methanogen, Methanococcoides methylutens gen. nov., sp. nov. Appl. Environ. Microbiol. 45:684690.

18. Stetter, K. O. 1989. Methanolobus, p. 2205-2207. In J. T. Staley, M. P. Bryant, N. Pfennig, and J. G. Holt (ed.), Bergey's manual of systematic bacteriology, vol. 3. Williams \& Wilkins, Baltimore. 